ENTREPRENEURSHIP AND SUSTAINABILITY ISSUES

ISSN 2345-0282 (online) http://jssidoi.org/jesi/

2020 Volume 8 Number 2 (December)

http://doi.org/10.9770/jesi.2020.8.2(66)

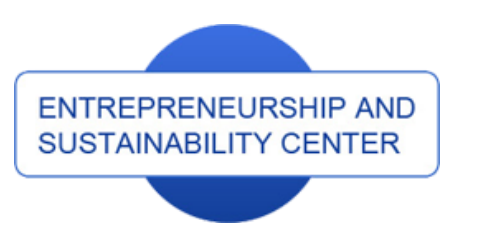

Publisher

$\underline{\text { http://jssidoi.org/esc/home }}$
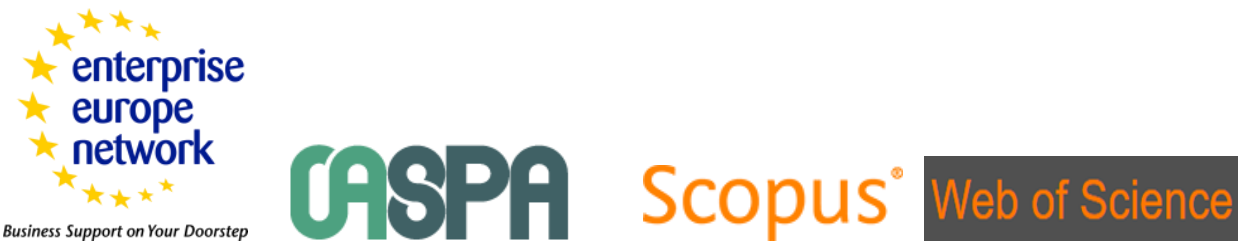

is Clarivate

Analytics

\title{
HIGHER EDUCATION INSTITUTIONS AND CORPORATE SOCIAL RESPONSIBILITY: TRIPLE BOTTOMLINE AS A CONCEPTUAL FRAMEWORK FOR COMMUNITY DEVELOPMENT
}

\author{
Christiana Kappo-Abidemi ${ }^{1}$, Ogujiuba Kanayo ${ }^{2}$ \\ ${ }^{1,2}$ School of Development Studies, University of Mpumalanga, South Africa \\ E-mails: ${ }^{1}$ C.Kappo-Abidemi@ump.ac.za; ${ }^{2}$ Kanayo.Ogujiuba@ump.ac.za (Corresponding author)
}

Received 18 May 2020; accepted 13 October 2020; published 30 December 2020

\begin{abstract}
Corporate Social Responsibility (CSR) is predicated on three organizational pillars of economic values, social values and environment values known as the "triple bottom-line". This framework refers to an accomplishment of a win-win status quo amongst three units. Stakeholders within the Higher Education Institutions (HEIs) somehow have ways of enforcing organizations to comply with these triple bottom-line. However, profit making is not applicable to a considerable extent in (HEIs) funded by government, but accountability is of paramount importance. On the other hand, HEIs are facing challenges induced by labour market dynamics. This article is a based on the triple bottom line conceptual paradigm and reviews CSR and the importance of the paradigm for HEIs in community development for developing countries, using South Africa as a reference point. We relied on existing literature and our analysis suggest that HEIs need to take part in profitable relations with several stakeholders while integrating their visions and purposes into their CSR management agenda. For the reason that the structure of the community is somewhat complex because of diverse personalities with different levels of resource control; adopting CSR would benefit, appropriate integration of community development programmes.. Engagement through CSR will enhance mutual trust, reduce protest and help improve public image of the HEIs. Particular emphasis on HEIs support to economic welfare and social environs would be a value addition to community development.
\end{abstract}

Keywords: Stakeholders, Community Development, Corporate Social Responsibility, Triple bottom-line

Reference to this paper should be made as follows: Christiana-Kappo, A., Ogujiuba. K. 2020. Higher education institutions and corporate social responsibility: triple bottomline as a conceptual framework for community development. Entrepreneurship and Sustainability Issues, 8(2), 1103-1119. http://doi.org/10.9770/jesi.2020.8.2(66)

JEL Classifications: I10, I18, I20

Additional Information: Political Sciences; Sociology, Environment 


\section{ENTREPRENEURSHIP AND SUSTAINABILITY ISSUES}

ISSN 2345-0282 (online) http://jssidoi.org/jesi/

2020 Volume 8 Number 2 (December)

http://doi.org/10.9770/jesi.2020.8.2(66)

Make your research more visible, join the Twitter account of ENTREPRENEURSHIP AND SUSTAINABILITY ISSUES: @Entrepr69728810

\section{Introduction}

Development organizations for example, the United Nations, the World Bank and many others views Corporate Social Responsibility (CSR) as a prospective apparatus for generating development (Frynas, 2005). According to the DFID, in following socially accountable practices, the development that will be stimulated by the private sector will be more all encompassing, impartial and poverty dipping (Jenkins and Ogbara, 2008). As the public expectations of CSR endure and increase because of the bigger role Higher Education Institutions (HEIs) are playing in the public sphere, some HEIs are still looking for ways and means to incorporate CSR into their longterm business stratagems in a way that is advantageous to both education and society. Even though it is debated that being socially responsible does not at all times grow the financial bottom line; there are numerous cases of organizations that have remained profitable while applying more socially and environmentally accountable business models. Hence, promoters of CSR believe that in addition to or in the nonexistence of government regulation, CSR may well be an operational way for organizations to amend the negative effects of Foreign Direct Investment (FDI) and aggressively contribute to community development in a sustainable way.

The question of corporate social responsibility (CSR) has been in discourse for a very long time dating to the 1960s. Nonetheless, seminal research from Secchi (2007) and Lee (2008) echoed in Agedelo et al, (2019) show that the connotation of Social Responsibility has been varying in implication and practice. The orthodox view of the issue was narrowly restricted to charity and then moved to the importance on business-society relations. For the most part, this opinion referred to the contributions made by corporations towards resolving social problems. At the beginning of the twentieth century, social performance connected with market performance of corporations. Oliver Sheldon (1923, cited in Bichta, 2003), the proponent of this philosophy nevertheless, was on the side of management to take the creativity in increasing both ethical standards and justice in society through frugality. In doing so, commerce generates prosperity in society and provides improved levels of wellbeing. Consequently, the present-day corporate responsibility is a structure whereby business organizations consider the concerns of society and accept accountability for the effects of their activities on all, including the business environment. This responsibility shows that the organizations have to act in accordance with legislation and of their own accord create enterprises to increase the well-being of their employees. The HEIs are public entities governed autonomously and regarded as social resources (Ketschau, 2017). The educational system all over the world is latent with different challenges; some of the challenges are peculiar to a particular country while others could be generic. Likewise, communities in developing countries rely on the presence of government and non-governmental organizations to provide their needs, which could be healthcare, improved economic activities, employment generation and so on. Mutual understanding amongst stakeholders is achievable through engagement and proper consultation. Reiss in his interview with Rodney Martin, CEO, Voya Financial, a leading company that helps Americans plan and invest, brings forward his interviewee comment, Corporate responsibility comprises key characteristics of a business culture, such as integrity and transparency; diversity, equality; sustainability; governance; and volunteerism, philanthropy amongst others (Reiss, 2017).

CSR is continuous and long-term process guided by organization personal values. Concisely, Nwoba \& Michael (2016) described CSR as the strategies adopted by organization to conduct business in an ethical, societal friendly and beneficial manner to community in term of development. CSR is expected to be a collective effort of all stakeholders through engagement and interaction at all levels. This can involve; working in partnership with local communities, developing relationship with employees and customers, social responsible investment and environmental protection and sustainability. Stanislavska, Kvasnicka, Kuralova \& Margarisova (2014) also explained CSR as voluntary interaction of the organization with stakeholders. However, in South Africa CSR has been made mandatory to companies in order to be BBBEE and Corporate Governance compliant but it is expected 


\section{ENTREPRENEURSHIP AND SUSTAINABILITY ISSUES}

ISSN 2345-0282 (online) http://jssidoi.org/jesi/

2020 Volume 8 Number 2 (December)

http://doi.org/10.9770/jesi.2020.8.2(66)

Make your research more visible, join the Twitter account of ENTREPRENEURSHIP AND SUSTAINABILITY ISSUES: @Entrepr69728810

to be applied in relevant to the situation (Solomon, 2013). Corporate social responsibility is universally significant as the continuing responsibility by corporate organizations to act virtuously and support economic development in-addition to increasing the value of life of the employees and their relatives as well as the local community and society in general (Alzyoud \& Bani-Hani, 2015). The ultimate aim of the corporation is not just the success of business but the welfare of the society at large. Similarly, the society also become interested and concerned about the business. Hence, the emphases is on the need to reconcile ethic with business by doing what is right for the survival of the planet and the life it supported. Progressively, corporations are displaying their corporate social responsibility actions, which boost Organizational appearance; this in turn, provokes positive public opinions Pang, et.al 2018). Owing to its market size and potential, the number of contending initiatives in Africa is increasing. In the foods and beverage industry for instance, corporations attract customers through promotional activities such as Advertising and Public Relations. Therefore, how to accomplish and maintain a savory appearance is a significant concern. Shu-Ling Hsu opined that corporations must launch their organizational image to stabilize their market place (Shu-Ling, 2018).

Higher Education Institutions are not completely exonerated from CSR because they are not hundred percent funded by the government despite being an autonomy entity. The activities of the HEIs in anyway are not expected to be detrimental to the society and environment. Bowens (2011) further explained that CSR influences issues such as civil rights, environs, labour, non-discriminatory operating practices, opposing exploitation and consumer protection. International Organization Standardisation 26000 article recommendations on CSR is also centred on the feedback of stakeholders from developing countries, business, government, consumers, labour, non-governmental organizations and others. Thus, the report articulates the views and perception of almost all pertinent parties and businesses. In recent years South African higher educational institutions have been faced with so many challenge such as induced from poverty amongst certain racial groups that lead to quest for free education, decolonisation of education, massification of education and politicalising of education (Kekana \& Kubheka, 2016; Mabelebele, 2015). Public HEIs in South Africa is funded via government grants (50\%), student tuition fees (25\%) and other private income (25\%) (DHET, 2004; de Beer, Jacobs, Moolman \& Zaaiman, 2016). Some institution also have a way of generating income internally. Despite the enormous dependent on public funding, HEIs are also expected to abide by the provision of King IV report, whereby 'triple bottom line' baseline for measuring organizational performance is adopted (van der Walt, 2013). Historically, South African education system has not been receptive to people of coloured (Ramdass, 2009). At the dawn of democracy, various policies and laws were enacted for an all-inclusive relationship in every sphere of the society. In as much as the new democratic policies has opened the door of learning, the system is still been haunted by the ghost from the past (DHET, 2010; Badat, 2010). In South Africa, HEIs has been subjected to pressures such as fees must fall in the recent time. The mandate has pressurised the government to provide free education for all in South Africa in such a way that the HEIs has been in turmoil in the last 5 years. The demand of students for free education seems unending and the department is struggling to meet up with all of it (Masweneng, 2017). In addition, employees through their unions have also had expectations such as converting all temporary/contract non-skilled employees into permanent position, which sometimes end up in deadlock. HEIs do experience infrastructural challenges due to student influx, which requires government intervention. Host communities of HEIs have also to endure the protests and unrest that accompanied the demands of these internal stakeholders.

Nonetheless, interested party identification and administration is reasonably well understood in the literature for private sector organizations (Christopher, Payne, \& Ballantyne, 2002, Rutterford, Upton, \& Kodwani, 2006), and its importance is rising through all developing and developed countries (Maassen 2000, Wit, \& Verhoeven, 2000, Peters 1996, Kettle 2002, Fasoulis, \& Kurl, 2018; Girdzijauskaite, Radzeviciene, \& Jakubavicius, 2019). In contrast, where stakeholder theory has grown in commercial arenas (Donaldson, \& Preston, 1995), there are fewer studies in the public and not for profit areas (Bryson 2004), typically with respect to higher education institutions. 


\section{ENTREPRENEURSHIP AND SUSTAINABILITY ISSUES}

ISSN 2345-0282 (online) http://jssidoi.org/jesi/

2020 Volume 8 Number 2 (December)

http://doi.org/10.9770/jesi.2020.8.2(66)

Make your research more visible, join the Twitter account of ENTREPRENEURSHIP AND SUSTAINABILITY ISSUES: @Entrepr69728810

Higher Education Institutions (HEIs) represent a vital body part of any society. These institutions are facing new challenges that impose the need to be independent to a reasonable extent from governmental and state support. The South African changing environment in which HEIs function and the challenges that higher education face comprise mass increase of higher education; reduction of state expenditure and support; diversification of financial resources; internationalization; commercialization; changes brought by technology development, the adaptation of core curriculum to accommodate and capitalize on labour market requirements. These changes, no doubt have affectedthe quality of education, HEI autonomy, academic freedom and responsibilities towards society. Thus, HEIs are are moving toward corporatization which calls for them to be a good corporate citizen and the best approach for them to achieve that is by adjusting to the model of Social Responsibility. This article focuses on the necessity for higher education institutions to demonstrate responsible corporate citizenship to their diverse stakeholders, within the context of a developing country epitomized by South Africa. Hence, we focused on the level of engagement the stakeholders should expect as well as determine the role of HEIs in CSR for sustainable community development.

\section{Theoretical Framework}

Our paper is predicated on the stakeholder theory as propounded in 1948 by Edward Freeman. The principle postulates that organizations owe answerability as well as responsibility to extensive variety of stakeholders, other than just shareholders. These interested parties represents to all who affect or are influenced by organizations' actions. Astrie, Gatot and Yuni 2014 did hypothesize that these interested parties encompasses investors, suppliers, customers, employees, government, community and the environment. The key proposition of the philosophy is that organizations owe corporate accountability to broad range of stakeholders' interest. It considers an organization as an interconnected web of varied interests. According to Lin, the stakeholder theory is a theory of organizational management and business ethics that accounts for multiple constituencies impacted by business entities like employees, suppliers, local communities, creditors, and others. It asserts that managers must satisfy a variety of constituents who can influence the firm's outcomes and addresses morals and values in managing an organization, such as those related to corporate social responsibility, market economy, and social contract theory (Lin, 2018). The proponents accepted this theory as one of the schemes in humanizing the organization of firms' social responsible behaviour. The foundation for adopting this theory for this paper is that the discourse is around the framework of organizations' social responsibility schedule to generate development within its host community ultimately.

\section{Triple Bottom Line Framework}

The triple bottom line (TBL) is a concept that inspires organizations' pledge on social and environmental apprehensions just as they do on income flows. The TBL theorizes that as an alternative of one bottom line, there ought to be three: people, profit and the planet. This framework measures an organizations level of obligation to corporate social accountability and its impact on the environment in due course. A renowned British Management professional (John Elkington) in 1994, created the slogan "triple bottom line" as his way of gauging performance in corporate America. The principle behind the TBL was that organizational goals could be achieved in a way that not only profits is considered, but also people's lives are advanced and the planet protected. In corporate finance, when we refer to a firms' bottom line, we usually mean its profits and this is line with tradition, where corporate leaders concern themselves with the bottom line (monetary profits their businesses makes). However, Elkington's TBL framework supports the goal of sustainability in business practices, where organizations move outside profits to include social and environmental concerns to gauge the complete cost of doing business.. The TBL framework increases the old-style bookkeeping structure to encompass additional 
ENTREPRENEURSHIP AND SUSTAINABILITY ISSUES

ISSN 2345-0282 (online) http://jssidoi.org/jesi/

2020 Volume 8 Number 2 (December)

http://doi.org/10.9770/jesi.2020.8.2(66)

Make your research more visible, join the Twitter account of ENTREPRENEURSHIP AND SUSTAINABILITY ISSUES: @Entrepr69728810

performance areas: the social and environmental influences of organizations. These three fundamental dimensions are denoted as the three P's: people, planet, and profit (Figure 1).

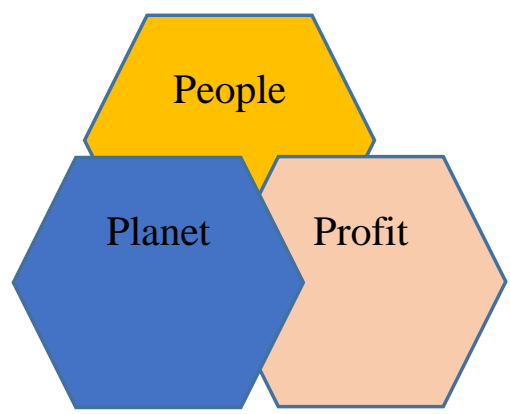

Figure 1: Triple Bottom Framework Source: Authors

People refers to employees, the labor involved in a corporation's work, and the wider community where the firm operates. The importance is on how much an establishment supports the society. A triple bottom line organization pays a reasonable wage and ensures a good working condition at all units. Triple bottom line organization make an effort to give back to the community. This ingenuity is an example of "enlightened self-interest". The planet element of the triple bottom line specifies that corporations must decrease their environmental footprints as much as possible. These determinations should embrace financing renewable energy, managing natural resources efficiently, and improving the reduction of waste. Nevertheless, though every organization pursues profitability (financials), organizations embedded in the triple bottom line see it as part of a business plan. Therefore, sustainable organizations have acknowledged that profit is not entirely conflicting with people or the environment. TBL theory posits that businesses should be operating concurrently on the three bottom lines: People, Planet and Environmental Responsibility. Profit, is referred to the traditional corporate profit, the people measures how socially accountable an organization has been throughout its tasks, while the Planet measures how ecologically accountable an organization has been. By focusing on these three interconnected essentials, triplebottom-line reporting can be a vital tool to supporting a firm's sustainability goals. Moreover, the TBL hypothesizes that if an organization highlights only finances and does not investigate how it interconnects socially, that organization cannot see the whole picture, and thus cannot account for the full cost of doing business.

Despite the fact, the triple bottom line has been in the dialogue for more than two decade, events such as the 2008 financial watershed, the British Petroleum oil spill, and climate variation discussions have continuously, casted spotlights on organization's ethics and their corporate social responsibilities. A more recent research at MIT found that establishments that treated sustainability with due recognition by making a business case for it with tangible goals were the ones that benefitted from sustainable activities. The achievement and practicality of business sustainability innovations is reliant on a gifted member of staff who knows how to take the triple bottom line from theory to reality. This worker must have a precise understanding of ecological science, bookkeeping, and economics. In addition, governance skills and the capacity to use systems thinking to make tactical corporate judgements are also significant for the employee. 


\section{ENTREPRENEURSHIP AND SUSTAINABILITY ISSUES}

ISSN 2345-0282 (online) http://jssidoi.org/jesi/

2020 Volume 8 Number 2 (December)

http://doi.org/10.9770/jesi.2020.8.2(66)

Make your research more visible, join the Twitter account of ENTREPRENEURSHIP AND SUSTAINABILITY ISSUES: @Entrepr69728810

\section{Review of the Legal Framework for Coporate Social Responsibility in South Africa}

Coporate Social Responsibility (CSR) is not merely a recurrent theme for discussion and argument in South Africa, but also a noticeable effort by most establishments. The social image of South Africa after the Apartheid period was one of obvious dissimilarities as per education, substructure, financial power, and access to basic services. The democratic administrations that have administered the country from 1994 have made significant efforts in contending with obvious social inequities through diverse social agendas and several public initiatives, in-addition to the gravitas given to the private sector. Even though the South African Companies Act 61 of 1973 does not indulge businesses to participate in CSR ventures, the policy document of the country and the King II and King III reports clearly support the need and significance for businesses to recognize all interested parties and to embrace a "triple-bottom line" approach (Dekker and Esser 2008). Specifically, the King reports, focuses on social, environmental and economic concerns, which constituted accepted guides of finest practices in corporate governance in South Africa.The clauses in the reports are not compulsory, but they take a "comply/apply or explain" method that to some extent forces businesses to apply CSR programs or rationalize why they have not implemented them (Sustainability SA).

Nonetheless, according to existing studies, not all CSR initiatives in South Africa result from voluntary or indirect business resolutions. Most of them are the creation of corporate acquiescence with the Black Economic Empowerment (BEE) legislation (Sustainability SA). The BEE Act mandates South African-based businesses to consider all stakeholders when carrying out their internal and external processes in an effort to eliminate societal and economic imbalances inherited from Apartheid era and support previously discriminated groups to enthusiastically play a part in the country's economy. Corporations that refuse to comply with the BEE scorecard are given negative ratings, therefore complicating their capability to operate in the country. At the end, BEE is not entirely planned to address racial inequities; it also tries to fortify the socioeconomic spectrum of the country for parity and fairness. Even though large multinational corporations are the ones that are more dynamic with CSR, more and more businesses from many sectors and of diverse sizes are begining to demonstrate interest in social responsible policies not only because of global rising trends and external pressures, but also because it can lead to efficiency gains. Porter and Kramer (2011) posit that solving societal worries may well increase the levels of company output, with the ensuing positive effects in profitability and shared values

The King Reports - the "Codex" of South African CSR

Corporate governance guidelines and standards in South Africa are entrenched in the well-known King reports (SAICA). Even though they are not approved legal documents; they are viewed as contemporary guiding principles on good corporate governance and its adoption is recommended in the country's business sphere. In 1994, the King Committee on Corporate Governance delivered the first report, King Report 1994, intended to stimulate corporate governance and satisfactory standards for board of directors of listed companies, financial institutions and some public enterprises. Although encouraging decent governance practices, the report also put emphasis on the need for corporations to be socially accountable in the areas and communities in which they operate. In 2002, the King II report on Corporate Governance was published. Relatively at the same time, the Johannesburg Stock Exchange (JSE) demanded listed companies to conform with the King report or else, explain why they were not following to the norm. The second document clearly established and explained the seven good corporate governance fundamentals that any corporation embracing the report should pay attention to: accountability, discipline, fairness, independence, responsibility, social responsibility and transparency. The revised third issue of South Africa's Code of and Report on Governance Principles (King III report) was made operative in March 2010. With respect to the earlier versions, the 


\section{ENTREPRENEURSHIP AND SUSTAINABILITY ISSUES}

ISSN 2345-0282 (online) http://jssidoi.org/jesi/

2020 Volume 8 Number 2 (December)

http://doi.org/10.9770/jesi.2020.8.2(66)

Make your research more visible, join the Twitter account of ENTREPRENEURSHIP AND SUSTAINABILITY ISSUES: @Entrepr69728810

new report emphases sustainability and risk issues, while continuing to highpoint the significance for companies to respond to all stakeholders. The areas covered in the report are the governance of risk, the governance of information technology, compliance with laws, rules, ethical leadership and corporate citizenship, boards and directors andaudit committees. Others include codes and standards, internal audit, governing stakeholder relationships and cohesive reporting and disclosure. Indirect regulatory actions, like the groundwork and dissemination of the previously mentioned documents, can without a doubt help stimulate CSR initiatives in diverse industries. That is also the case of the launch and growth of the Johannesburg Stock Exchange Social Responsibility Index (JSE SRI) in 2004. The SRI apprises financiers and market go-betweens about corporate sustainability policies and practices of listed companies, encouraging investors to support "friendly" companies, and pushing corporations to strengthen their environmental, social and governance enterprises. Responsible investment is a comparatively new concept (the Dow Jones Sustainability Indexes were introduced in 1999 and the FTSE4 Good Index Series was launched in 2001), especially in emerging markets where South Africa was the first one in launching a sustainability index, followed by Brazil in 2005 (BM\&F Bovespa) (Accountancy SA 2001). According to King IV Report (2016) the organization values statements, usually state how all stakeholder both internal and external will be treated, the purpose and objectives of the organization, expectations of how work is done and how stakeholders should behave (IODSA, 2016). These values are expected to reflect in organization vision and mission statements and addresses the ultimate aims of CSR. Ethical issues are also one of the major concerns of CSR.

\section{Stakeholders In HEIs and Corporate Social Responsibility}

Freeman (1984) posits that an interested party may be any individual or group of individuals either impacted upon by the corporation or able to influence on the attainment of its goals. This is the conception behind Stakeholder Theory. The theory cogitates that the consequences of any activity should take into consideration the benefits for all interested parties involved and not only those of the shareholders. Within the context of public and not for profit organizations, Bryson (2004) in reaction to the Eden and Ackerman of 1998, identified interested parties as individuals that have the power to firmly effect, the future of the organization. Furthermore, Jongbloed et al. (2007) joined the debated and pointed out that the acceptability of higher education to the public is gauged continually by the dimension and prominence of the HEIs obligation to its community of stakeholders, which is essentially of superior depth than any modest maintenance of contacts. It realistically portends that the organization seeks out and embraces ways of including the stakeholders to best perceive how the latter, value the services provided and just how they will advance. Benneworth and Arbo (2006), argue that a plausible importance from the above discourse is that these demands will induce a new method to governance and social accountability, improved professional management and a reassessing of the university business models for developing countries. Jongbloed et al., (2007) inclined that the stakeholder theory is outstandingly valuable to HEIs in describing the attention provided to the many groups found in its environment additionally to the relational interface between HEIs and its communities. Nevertheless, amongst developing countries, South Africa inclusive, HEIs are yet to prove their competence to fittingly identify the stakeholders working with the institution as well as establish the needs of each entity and the level of prominence to accord to each relationship. However, for HEIs in the developing countries to meet stakeholder needs, much has to be done.

HEIs in South Africa have four basic pillars for assessing performance, which are teaching, and learning, research and scholarship, engagement and leadership, administration and management. Alzyoud \& Bani-Hani (2015) explained that CSR could be achieved through all of these university core businesses. The South African department of higher education (DHET) in its value statement prioritised the need to address society problem through education and training, complied with the constitutional mandate of right to education and acknowledge 


\section{ENTREPRENEURSHIP AND SUSTAINABILITY ISSUES}

ISSN 2345-0282 (online) http://jssidoi.org/jesi/

2020 Volume 8 Number 2 (December)

http://doi.org/10.9770/jesi.2020.8.2(66)

Make your research more visible, join the Twitter account of ENTREPRENEURSHIP AND SUSTAINABILITY ISSUES: @Entrepr69728810

the need to work with all partners to achieve their goals. Furthermore, DHET value statements will help the stakeholders to know if the HEIs are keeping to their promises or not (Dubbink, Craafland \& Liedekerke, 2014)

The implementation of CSR by the HEIs supposed to be the joint effort of the stakeholders within and outside the institutions (Bowen, 2011). Nonetheless, it is expected that individual institution may adopt a framework of values, mission and vision from the generic provision of the DHET. However, this is not an innovative approach to CSR, because as clearly mentioned in ISO 26000 document, there are lot of unidentified stakeholders in each organization. The onus thus lies on individual organization to identify people affected by their operations, their concerns and methods of engagement. Consequently, seven ideologies of social responsibility has been identified by Bowens (2011) as accountability, transparency, moral behaviour, reverence for stakeholder interests, reverence for international rules of behaviour and reverence for human rights. These values must be integrated in HEIs community development approaches

Stakeholders are described as the group of individuals that are interested in the business of the organization, these individual can be affected by the outcomes of the organization objectives and decisions (Khanyile, 2018). In order to determine the stakeholders in HEIs, it is recommended that the purpose and objectives of the institution as well as management responsibility towards the stakeholders should be identified. Stakeholders in South African higher education institutions involve both internal and external individuals that have stakes in the activities of the university and are affected by these activities. The internal stakeholders are clearly identified as students, government, staff (academics and administrative staff). The external stakeholders are a bit ambiguous and can only be defined according to various institutional plan within the provision of DHET. However, external stakeholders are identified as graduate students, employers of graduates, funding agencies and society (Stanislavska, et al, 2014: Badat, 2010; Vasilescu et al, 2010: Chen, Nasongkhla \& Donaldson, 2015). The stakeholder theory further explain that the corporation activities have the right and obligation to participate in directing it (Brusseau, 2012) affects whoever's life. As such, the HEIs are expected to pursue and embrace their ideologies and principles: even-handedness, excellence, development, democratization, academic liberty, institutional sovereignty, effectiveness, efficiency, and public accountability in the interest of all (DBSA, 2010).

\section{Corporate Social Responsibility of Higher Education Institutions}

Corporate Social Responsibility is not just limited to philanthropic responsibility, of the business, also, economic responsibility, legal responsibility as well as ethical responsibility were all considered as holistic approach to CSR (Brusseau, 2012; Vasilescu, Barna, Epure \& Baicu, 2010). The CSR is globally underlined with come certain principles which can be compared with the values and principle set for HEIs in South Africa and establish the possibility of pursuing social responsibility within the community by universities despite been a public entity with autonomy power. Actually, education is regarded as one of the most powerful tool needed for the pursuit of the agenda of CSR by linking economic, societal and environmental to sustainable development strategy for national improvement (Chen, Nasongkhla \& Donaldson, 2019). Further, Sham (2018) posits that "destroying any nation does not require the use of atomic bombs or the use of long range missiles. It only requires lowering the quality education and allowing cheating in the examination by students". This will destroy the entire governance system because it will be populated by mediocrities produced from such education system. This position is also in tandem with Rahman et al (2019). The impact of HEIs is illustrated in below figure 2: 
ENTREPRENEURSHIP AND SUSTAINABILITY ISSUES

ISSN 2345-0282 (online) http://jssidoi.org/jesi/

2020 Volume 8 Number 2 (December)

http://doi.org/10.9770/jesi.2020.8.2(66)

Make your research more visible, join the Twitter account of ENTREPRENEURSHIP AND SUSTAINABILITY ISSUES: @Entrepr69728810

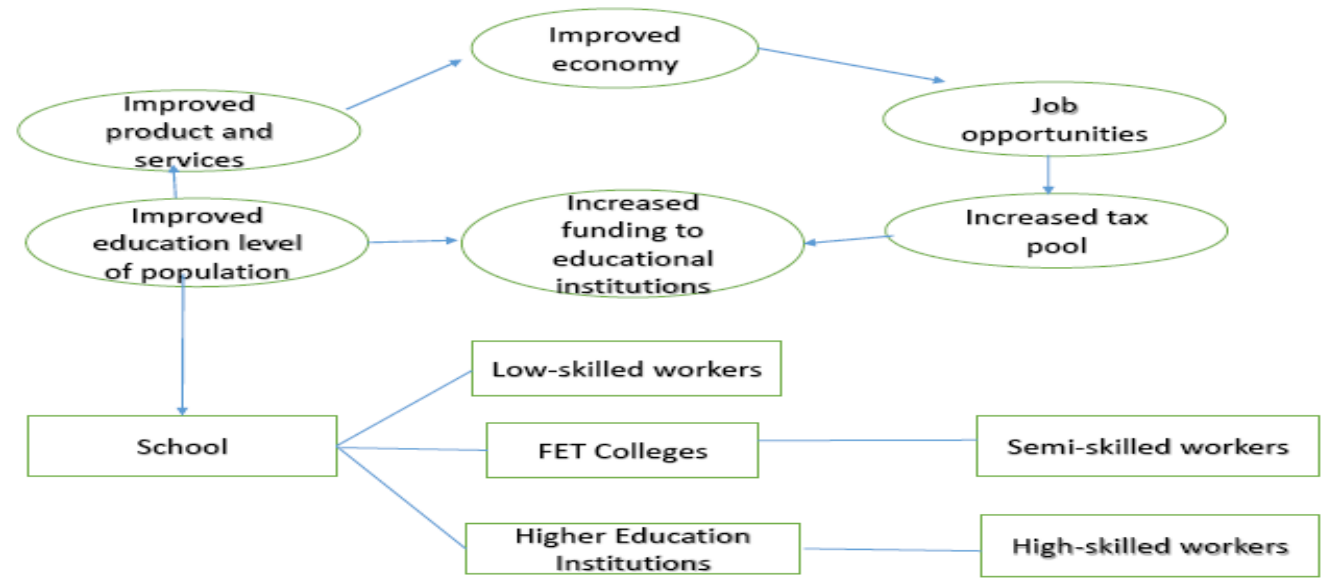

Figure 2: Illustration of HEIs impact on economy

Source: Adapted from (de Beer, Jacobs. Moolman \& Zaaiman, 2016)

In line with the principles of CSR and the highlighted impacts of HEIs, below discussions is going to examine the relationship between the principles and how they impact on the university communities.

\section{a. Corporate social responsibility accountability and HEIs}

The objective of this principle is to ensure that corporate decision is taken in such a way that both organization and stakeholder's interest are put into consideration without having to deceive any of the parties (Jones, 2010). Accountability is usually described based on the context in which it is been used, however, in the context of CSR, triple bottom-line is regarded as the appropriate measure for corporation accountability. Whereby, an organization are expected to keep proper records of their economic, social and environmental activities (Brusseau, 2012; Mosunova, 2014; Yamamoto, 2011). In the past, business were only accountable to the shareholders, as time goes by the role changed and all stakeholders are entitled to reports, not just on finances but other activities of the organization that impacted on stakeholders. Yamamoto (2011) acknowledged that the merging of autonomy power and accountability granted HEIs has somehow subjected its operation to performance based funding. The performance are measured in term of graduate throughput and research articles published in accredited journals (Mohamed, 2015) and how these has impact on relevant stakeholders. HEIs are not excluded from being accountable to their stakeholders despite been a public entity. In the last four years South Africa Higher institution has been facing various challenges in term of undergraduate funding which was titled \#feesmustfall. In a study done by (Inglesi-Lotz \& Bohlmann, 2016) explained the ripple effect of fees must fall protest on the economy and labour marker. The analysis in the study showed that there might about $90 \%$ reduction in new skill labour entering into the market. This challenge has brought on board more stakeholders into limelight. HEIs has been forced to engage more with government, business, parent, and student formations to discuss way forward (Masweneng, 2017). In addition, the presence of universities in communities has brought about changes in social, economic and environmental structure of such communities due to influx of young people for learning purpose. University students do have a way of affecting the social dynamics of their host community either positively or negatively depending on individual perception of their presence (Moolman \& Jacobs, 2018). Likewise, since universities are funded by taxpayer's money, hence, there is a serious need for an ongoing updates on their various activities on 


\section{ENTREPRENEURSHIP AND SUSTAINABILITY ISSUES}

ISSN 2345-0282 (online) http://jssidoi.org/jesi/

2020 Volume 8 Number 2 (December)

http://doi.org/10.9770/jesi.2020.8.2(66)

Make your research more visible, join the Twitter account of ENTREPRENEURSHIP AND SUSTAINABILITY ISSUES: @Entrepr69728810

regular basis especially the ones mandated by law such as demographic representation of workforce and given preference to deserving black learners. Actually, Mohamed (2015), suggested that responsibility is equal to accountability as per HEIs and its CSR operations

\section{b. Corporate social responsibility transparency and HEIs}

Despite the acclaimed academic freedom of HEIs, transparency and credibility is key to the appropriate management of its affairs. Right from inception universities has always been part of their host communities, and always seen and treated as one of the community entity (Die Arbeitgeber, 2009). Transparency with regard to CSR means disclosure of all relevant business information to stakeholder and ensure the business is devoid of corruption in any form. This could enhance the trust of employees, clients, community and other relevant stakeholders in the case of HEIs. The trust will establish the basis on which the stakeholder's conflict can be resolved amicably and successfully, attract and retain the best brain and promote the existing relationship in the right direction (Aggeri \& Breton, 2016). According to (Vasilescu et al, 2010) stakeholders demand and expected increasing standard of accountability and transparency at all time. According to (Nwete, 2007) CSR is described as the obligation of business to support economic development in a sustainable manner, in partnership with employees and their families, local community and society in general to progress quality of life that supports the business and good for development.

\section{c. Corporate social responsibility ethical behaviour and HEIs}

Business ethics is a "form of applied ethics or professional ethics that examines the ethical principles and ethical problems which arise in a business environment" (Wlodzimierz and Szanto, 2018). Mohamed (2015) described corporate social responsibility in academics/university environment as social responsibility, which is showed as the policy of ethical quality of performance of the university community through accountable management to generate Sustainable Human Development. Vasilescu et al, 2010, has suggested numerous CSR effects of the HEIs, which are organizational, cognitive, social and educational effects. In support of this framework, Mcuddy, Anstett \& Guest (n.d) designated ethical behaviour as what is accepted as good and right in the perspective of the governing moral code. Sometimes some things that seems legal may not be morally right. Hence, ethical behaviour is about striking a balance between legal and moral justifications. Unethical behaviours in HEIs can impact negatively on the thinking and moral of future leaders (Singh \& Stuckelberger, 2017). Student that learned in the course of their study that situation can be manipulated to suit their own expected purpose will definitely cheat their way through in business after graduating from higher institution of learning. Hence, the need to instil ethical behaviour into learners is one way of HEIs involving in corporate social responsibility (Chen, Nasongkhla \& Donaldson, 2015; Tormo-Carbo, Oltra, Segui-Mas \& Klimkiewicz, 2016; Singh \& Stuckelberger, 2017)). The HEIs itself has to have high ethical culture in how it relates with stakeholders just like other business organization, there is need to comply with recordkeeping and report on its activities as it impacts on society and environment. Ike (2017) acknowledged that education does not happen in isolation but through societal, environmental and human influences. Educational institutions should revisit their curriculum and engage in teaching, research and training that challenges the entire conscience of human.

There are various ethical issues in HEIs that can negatively impact on Corporate Social Responsibility all over the world and South Africa included. Collapse of multinational companies earlier in $21^{\text {st }}$ century has raised a lot of questions and integrity on academic institutions that produced the likes of managers that were involved in corruption stories that surrounded the collapse of those companies (Stuckelberger, 2017). Likewise, in South Africa, student funding through NSFAS over the years has been characterised by lots of hiccups that created students unrest and protest. Administrators has been accused of malpractices. Communities has been place on 


\section{ENTREPRENEURSHIP AND SUSTAINABILITY ISSUES}

ISSN 2345-0282 (online) http://jssidoi.org/jesi/

2020 Volume 8 Number 2 (December)

http://doi.org/10.9770/jesi.2020.8.2(66)

Make your research more visible, join the Twitter account of ENTREPRENEURSHIP AND SUSTAINABILITY ISSUES: @Entrepr69728810

siege sometimes due to student unrest, life and business of the community has also been threatened in the course of the protest. The DHET policy on throughput of graduate has put educators under unnecessary pressure to increase the pass rate. In some cases underserving students marks are upgraded in other to meet the expected passed rate or the quality of the assessment questions and criteria are reduced to increase the pass rate (Jacobs \& Moolman, 2018).

\section{d. Stakeholders Interest and Corporate Social Responsibility}

Stakeholders are basically categorised into two namely: primary and secondary stakeholders. The primary stakeholders have direct interest on the organization performance and manners in which the organization have conducted business. Meanwhile, the secondary stakeholders are indirectly affected by the organization through their actions (Saylor Foundation, n.d). Stakeholders might be a source of new ideas, innovations and opportunities for organization growth and development. However, the stakeholder interest concept of CSR was born out of the fact that any activities of an organization that endanger the live or property of others must have a dare consequence on the organization (Nikolova \& Arsic, 2017). According to Kettune (2014), quality assurance document of the institutions must describe the level of interactions and relationships with all stakeholders in HEIs, especially the external stakeholders. The terms and conditions of engagement and involvement of stakeholders in HEIs affairs should be clearly stated in policy document. In addition, HEIs could collaborate with more stakeholders in order to generate funds for the administration of the institution. Stakeholders are not just people that contributed to the organization in one form or the other; people affected by the activities of the organizations are also regarded as stakeholders. For instance, in the case of HEIs, always a government gazette precede the establishment of HEIs in any community. In this document people that were likely to be involved and affected by the affairs of the institution are usually mentioned and mode of engagements with them.

\section{Community Development Via CSR: Role of HEIs}

The days when the government was seen as the exclusive social change agent and the total macro problem solver have become an obsolete thinking, as organizations are increasingly taking a larger role, actively contributing in social and community projects under the concept of Corporate Social Responsibility (CSR). The featuring part of HEIs CSR in Community Development (CD) used in this paper is every primary and secondary benefits received by the community because of social obligation of the HEIs to the general community and social system. In accordance with the espoused principles as stated by Bowens (2011), we signpost the collective roles of HEIs CSR in CD for developing countries:

a. Closer links between HEIs and Communities. Via CSR, the presence of HEI in the social structure is felt beyond the realm that HEI is a structure for job creation and production of services only. This felt social capital in the society is consequently essential for community development; thus, HEIs and host societies stays in perpetual concord.

b. Growing talents. HEIs with a progressive approach towards CSR can profit from their position and fortify their posture as an attractive establishment by making their guarantee part of their value proposition for would-be employees. Research has confirmed that when employees view their organization's commitment to socially answerable behaviour more favourably, they correspondingly gravitate to have attitudes that are more constructive in many other areas that associate with better performance. They have confidence in their organizations, to make out, recompense great service, and resolve apprehensions quickly. A stout confidence in senior administration as per CSRs, results to improved opinion of employees to HEIs, hereafter their persuasion and devotion to the sector. This is vital in acquiring and retaining skilful 


\section{ENTREPRENEURSHIP AND SUSTAINABILITY ISSUES}

ISSN 2345-0282 (online) http://jssidoi.org/jesi/

2020 Volume 8 Number 2 (December)

http://doi.org/10.9770/jesi.2020.8.2(66)

Make your research more visible, join the Twitter account of ENTREPRENEURSHIP AND SUSTAINABILITY ISSUES: @Entrepr69728810

employees in the HEIs. In relation to Community Development, HEIs personnel views would possibly result to a community that treats the HEI as a vital economic base in the society.

c. Transfer of Technology (TOT). Closer ties help in TOT between host communities and HEIs. Barton (2007) posits that there are three mechanisms of technology transmission: the flow of human resources; the flow of public technology support; and the flow of private technology to host communities. TOT introduced by HEIs that is rooted in the CSR processes, would profit the targeted communities in many facets of their development.

d. Interdependency between Communities and HEI: The close linkage observed between a HEI and community is a distinctive of CSR role in community development as it produces progress that is sustainable in the end. HEIs CSR ventures give backings to local organization and disadvantaged communities. This without reluctance leads community development in a sustainable manner.

e. Poverty Alleviation: HEIs program may well focus on the underprivileged, helpless and susceptible groups in the communities they function. Via this partnership, they may perhaps galvanize other organizations to help the host communities in its struggle to lessen poverty and, henceforth, in developing the communities.

f. Information Coordination Function: HEIs should produce evidence-based research and start developments that are paramount to their host communities with references from such research. For example, extra-large Information Tech companies in the United States assisted under-staffed police departments with information gathering and processing by connecting cameras with video processing capabilities in spaces where the crime rates were becoming very high (CSR@Intel, 2009). This is an instance of how technology companies implement CSR ingenuities, which correspondingly profit the community and support their business goals.

\section{Conclusion}

Previous literature have not investigated in detail how CSR should be focused towards skills and uplifting of previously disadvantaged persons in the South African Society. The COVID-19 pandemic have therefore presented a new vista for exploration as per the the workings of HEIs during this uncertainty. Furthermore, extant studies are silent on how operating doctrines that support development should be embedded int the CSR framework.

The general roles of corporate social responsibility (CSR) in community development revolve around the ways their responsibility is acknowledged by community of stakeholders and how they feel positive impacts. CSR have many functions, which are positive and they bring the effects of their actions to the community. For many HEI leaders, it is a challenge mostimes to know where their accountability should begin and end with reference to developing infrastructure, generating economic prospects, and giving access to core services. Nevertheless, experience has shown that long-lasting CSR solutions at any operational level are predicated on collaborations' amongst government, civil society and business. However, it should be noted that profits do matter in the triple bottom line, but not at the cost of social and environmental worries. Conversely, there can be dire costs of ignoring the TBL framework in the name of profits. A key challenge of the TBL, according to Elkington, is the challenge of evaluating the social and environmental bottom lines. Profit is fundamentally numerical, so it is easy to measure, but what constitutes social and environmental responsibility is to a certain degree subjective, which makes the evaluation difficult. For example, would a dollar measure the quantum of oil? Additionally, there is the concern of mingling varied elements. It is also problematic to change levers amongst priorities that are seemingly varied, make the most of financial returns while also doing the maximum good for society. Some establishments might struggle to balance deploying money and other resources, to all three bottom lines short of favouring one at 


\section{ENTREPRENEURSHIP AND SUSTAINABILITY ISSUES}

ISSN 2345-0282 (online) http://jssidoi.org/jesi/

2020 Volume 8 Number 2 (December)

http://doi.org/10.9770/jesi.2020.8.2(66)

Make your research more visible, join the Twitter account of ENTREPRENEURSHIP AND SUSTAINABILITY ISSUES: @Entrepr69728810

the expense of another. Most corporate social responsibility projects will not deliver an instant boost to HEIs financial performance, but implemented honestly and leveraged skilfully, they can bring positive publicity, enhance corporate reputation, and expand stakeholder engagement. This is in addition to giving HEIs, the contentment of knowing they have truly supported community development. The lack of transparency, neglection of the main business stakeholder and not introduction of criteria relative to the CSR outcome are key impediments to CSR in South Africa and most of developing countries that must be giving attention for progress in community development.

CSR of HEIs in most developing countries including South Africa differ because of context. Thus, this article posits that similar research should be steered on the discrepancies between methods implemented by HEIs in terms of emphases and configurations in Corporate Social Responsibility, the precise roles of Corporate Social Responsibility agendas to community and society. Specifically, the following recommendations are proffered:

1) The Corporate Social Responsibility of tertiary institutions, especially in South Africa should tend towards, skills and educational development of historically disadvantage people, creating employment opportunity for reasonable number of people within the local community.

2) Research focused on the workings of HEIs during the prevailing pandemic (COVID 19) and economic uncertainties would be invaluable. Nonetheless, HEIs should upbeat and acknowledge that moving to a balance of their financial books should not be at the expense of social goals that have obligation in keeping.

3) Change is a continuum and the HEIs globally are going through this process. Therefore, their responsibilities of learning and inquiries necessities a re-examination, with a view on the influence they make to the prosperity of their economic and social environs. Further, it is imperative that Educational programmes in emerging and developing countries should be organized in such a way that community wants will be met.

4) HEIs need to take part in cost-effective associations with several stakeholders and integrating their corresponding ideas and resolutions into their own management practices. Hence, HEIs need to make out these stakeholders and their desires before charting out priorities.

5) HEIs are encouraged to develop calculated trends and operating doctrines that guarantee sustainable performance and development. In such a process, the information learnt from the stakeholders and resultant inventions will allow the HEI to increase its performance in a way that will be sustainable in the long term. This will profit and add value, not only the institution, but also the stakeholders and society in general.

\section{References}

Accountancy SA (2001). The JSE SRI Index, http://www.accountancysa.org.za

Aggeri, F., \& Breton, M. (2016). The Regulation of Transparency in the Field of CSR: The Materialisation of an Ideal into Technologies of Government. EGOS, Naples, Italy.

Agedelo, M., Johannsdottir, L., \& Davidsdottir, B. (2019). A literature review of the history and evolution of corporate social responsibility. International Journal of Corporate Social Responsibility, 4(1), 1 https://doi.org/0.1186/s40991-018-0039-y 


\section{ENTREPRENEURSHIP AND SUSTAINABILITY ISSUES}

ISSN 2345-0282 (online) http://jssidoi.org/jesi/

2020 Volume 8 Number 2 (December)

http://doi.org/10.9770/jesi.2020.8.2(66)

Make your research more visible, join the Twitter account of ENTREPRENEURSHIP AND SUSTAINABILITY ISSUES: @Entrepr69728810

Alzyoudi, S.A., \& Bani-Hani, K. (2015). Social Responsibility in Higher Education Institutions: Application Case from the Middle East. European Scientific Journal, 11(8), 122-129.

Astrie, K., Gatot, Y., \& Yuni, R.B. (2014). Development path of Corporate Social Responsibility Theories. World Applied Science Journal (innovation challenges in multidisciplinary research and practice), 30(17), 110-120.

Badat, S. (2010). The Challenges of Transformation in Higher Education and Training Institutions in South Africa. Development Bank of Southern Africa.

Barton, J.H. (2007). New Trends in Technology Transfer: Implications for National and International Policy, Issue Paper No. 18. Geneva: International centre for Trade and Sustainable Development (ICTSD).

Benneworth, P., \& Arbo, P. (2006). Understanding the regional contribution of higher education institutions: a literature review. Paris: OECD/IMHE.

Bryson, J.M. (2004). What to do when Stakeholders Matter: stakeholder identification and analysis techniques. Public Management Review, 6(1), 21-53.

Bowens, R. (2011). Understanding the ISO 26000 Social Responsibility Standard and How it relates to and can be Assessed Alongside other Standards. A Discussion about Social Responsibility Issues and how they can be managed within Business for the Benefit of Society Today and in the Future. SGS.

Brusseau, J. (2012). Business Ethics. Available online at https://2012books.lardbucket.org/books/business-ethics/index

Christopher, M., Payne, A., \& Ballantyne, B. (2002). Relationship Marketing: Creating Stakeholder Value 2nd revised edition, Oxford, Butterworth-Heinemann).

CSR@Intel 2009. Does Technology have a role in Community Development? Available at http://blogs.intel.com/csr/2007/06

Chen, S., Nasongkhla, J., \& Donaldson, J. (2015). University Social Responsibility (USR): Identifying an Ethical Foundation within Higher Education Institutions. The Turkish Online Journal of Educational Technology, 14(4), 165-172.

De-Beer, E., Jacobs, L., Moolman, A., \& Zaaiman, R. (2016). \#Feesmustfall and beyond: Towards a Sustainable Student Loan Regulatory Framework-NWU View.

Dekker, A. \& Esser, I. (2008). The Dynamics of Corporate Governance in South Africa: Broad Based Black Economic Empowerment and the Enhancement of Good Corporate Governance Principles. Journal of International Commercial Law and Technology, 3(3) http://www.jiclt.com

DHET 2010. Report on the Stakeholder Summit on Higher Education Transformation. Available online at www.cput.ac.za/storage/services/transformation/he_transformation_summit_report.pdf

Donaldson, T., \& Preston, L. (1995). The stakeholder theory of the corporation: Concepts, evidence, and implications. Academy of Management Review, 20(1), 65-91.

Fasoulis, I., \& Kurl, R. (2018). Determinants to the implementation of corporate social responsibility in the maritime industry a quantitative study. Journal of International Maritime, SA Environmental Affairs, and Shipping, 10-20.

Freeman, R.E. (1984). Strategic Management, A stakeholder approach. Boston: Pitman Press

Frynas, J.G. (2005). The false development promise of Corporate Social Responsibility: evidence from multinational oil companies. International Affairs, 81(3), 581-598.

Girdzijauskaite, E., Radzeviciene, A., \& Jakubavicius, A. (2019). Impact of international branch campus KPIs on the university competitiveness: FARE method. Insights into Regional Development, 1(2), 171-180. https://doi.org/10.9770/ird.2019.1.2(7)

IODSA, (2016). The King IV Report on Corporate Governance for South Africa 2016. Johannesburg: Institute of Directors Southern Africa. 


\section{ENTREPRENEURSHIP AND SUSTAINABILITY ISSUES}

ISSN 2345-0282 (online) http://jssidoi.org/jesi/

2020 Volume 8 Number 2 (December)

http://doi.org/10.9770/jesi.2020.8.2(66)

Make your research more visible, join the Twitter account of ENTREPRENEURSHIP AND SUSTAINABILITY ISSUES: @Entrepr69728810

Inglesi-Lotz, R., \& Bohlmann, H. (2016). South Africa's economy would take a knock if starved of new graduates. Available online at http://theconversation.com/south-africas-economy-would-take-a-knock-if-starved-of-new-graduates-66578

Jerkins, H., \& Ogbara, L. (2008). Corporate social responsibility in the mini ng industries. The risk of community dependency. CCRP Queens University Belfast http://www.ccrconference.org

Jones, R. (2013). Corporate Governance and Accountability. "In Corporate Governance-Synthesis of Theory, research and Practice, edited by Ronald Anderson and Kent Baker, 559-576.

Jongbloed, B, Enders, J, \& Salerno, C 2007. Higher education and its communities: interconnections and interdependencies in higher education. Looking forward: Themes on the Changing Relationship between Higher Education and Society. European Science Foundation.

Kettle, D. (2002). The Transformation of Governance: Public Administration for Twenty-First Century America (Baltimore, MD: Johns Hopkins University Press).

Kekana, M., \& Kubheka, T. (2016). Shutdown of Universities will have 'Devastating Effects'. Speech delivered by Advocate Thuli Madonsela at Ahmed Kathrada Lecture in Johannesburg. Available online at https://ewn.co.za/2016/10/16/Shutdown-of-universities-willhave-devastating-effects

Khanyile, M. (2018). Essentiality of Stakeholder Management for University Survival. Available online at http://www.journals.ac.za/index.php/sajhe/article/view/1789/1846

Kettunen, J. (2014). The Stakeholder Map in Higher Education, Society, Education and Psychology, 78, 34-38. https://doi.org/10.7763/IPEDR.V78.7

Mabelebele, J. (2015). HE in South Africa: Emerging Challenges \& Implication for Universities. Available online at https://www.pwc.co.za/en/assets/pdf/he-conference_the-future-of-higher-education-in-south-africa.pdf

Lin, T.C.W. (2018). Incorporating Social Activism, Boston University Law Review, 1535, https://ssrn.com/abstract=3294317

Masweneng, K. (2017). Zuma's fee-free education does not tackle Fees Must Fall. Available online at https://www.timeslive.co.za/politics/2017-12-19-zumas-fee-free-education-does-not-tackle-fees-must-fall/

Moolman, A., \& Jacobs, L. (2018). Responses to the Short-Term effect of the Zero Percent fee increase of South African Universities. South African Journal of Higher Education. 32(1), 172-191.

Mohamed, A. (2015). A Framework for University Social Responsibility and Sustainability: The Case of South Valley University, Egypt. International Journal of Economics and Management Engineering, 9(7), 2407-2416.

Mosunova, N. (2014). The Content of Accountability in Corporate Governance. Russian Law Journal, 11(3), 116-129.

Nikolova, V., \& Arsic, S. (2017). The Stakeholder Approach in Corporate Social Responsibility. Engineering Management, 3(1), 24-35.

Nwete, B. (2007). Corporate Social Responsibility and Transparency in the Development of Energy and Mining Projects in Emerging markets: Is Soft Law the Answer? German Law Journal, 8(4), 311-340.

Nwoba, M., \& Michael, U. (2016). Community Development and Corporate Social Responsibility in Ebonyi State: An Investigation Study of Selected Mining Firms and Communities. Journal of Policy and Development Studies, 10(2), 54-62.

Pang, O.L., May, Chrystal, S.N., Ying-Kai, O. Shannon R.W., \& Kristle P.Y. (2018). Utilization of CSR to build organizations' corporate image in Asia: need for an integrative approach, Asian Journal of Communication, 28(4), 335-359.

Peters, B. (1996). The Future of Governing: Four emerging models (Lawrence, KA, University Press of Kansas). 


\section{ENTREPRENEURSHIP AND SUSTAINABILITY ISSUES}

ISSN 2345-0282 (online) http://jssidoi.org/jesi/

2020 Volume 8 Number 2 (December)

http://doi.org/10.9770/jesi.2020.8.2(66)

Make your research more visible, join the Twitter account of ENTREPRENEURSHIP AND SUSTAINABILITY ISSUES: @Entrepr69728810

Porter, M., \& Kramer, M. (2011) Creating Shared Value: How to reinvent capitalism-and unleash a wave of innovation and growth. Harvard Business Review, January-February.

Rahman, A., Castan, P., \& Love T. (2019). Corporate Social Responsibility in Higher Education. A Study of Institutionalisation of CSR in Malaysian Public Universities

Ramdass, K. (2009). The Challenges facing Education in South Africa. Paper presented at the Higher Education Conference on the Impact of Mergers on South African Higher Education System. Tshwane University of Technology, 2-7 October 2009.

Reiss, R. (2017) Top CEOs Place High Value on Corporate Ethics and Social Responsibility to Drive Business. https://www.forbes.com/sites/robertreiss/2017/09/11/top-ceos-place-high-value-on-corporate-ethics-and-social-responsibility-todrive-business/\#1cff9e794473

Rutterford, J., Upton, M., \& Kodwani, D. (2006). Financial Strategy: Adding Stakeholder Value, $2^{\text {nd }}$ edition, Chichester, John Wiley \& Sons).

SAICA, https://www.saica.co.za

Shu-Ling, H. (2018). The Effects of Corporate Social Responsibility on Corporate Image, International Journal of Social Sciences and Humanities Invention, 5(05), 4693-4703.

Solomons, N.M. (2013). The Role of Corporate Social Investment Initiative in South Africa Education. Unpublished Master's Thesis. North-West University.

Stanislavska L, Kvasnicka R, Kuralova K., \& Margarisova K. (2014). Social Responsibility of Higher Education Institutions- The Comparison of the vie of Students and Potential Students. Journal on Efficiency and Responsibility in Education and Science, 7(3-4), 9599.

Singh D., \& Stuckelberger, C. (2017). Ethics in Higher Education Value-driven Leaders for the Future. Globeethics.net Education Ethics, 1 Sustainability South Africa. King II Report on Governance in South Africa and King III report. http://www.sustainabilitysa.org

Tormo-Carbo G, Oltra, V, Segui-Mas E., \& Klimkiewicz, K. (2016). How effective are Business Ethics .CSR courses in Higher Education Advances, HEAd'16 21-23 June 2016, Valentia, Spain

Vasilescu, R., Barna, C., Epure, M., \& Baicu, C. (2010). Developing University Social Responsibility: A model for the Challenges of the new Civil Society. Procedia Social and Behavioural Sciences, 2, 4177-4182.

Włodzimierz, S., \& Szántó, R. (2018) Corporate Social Responsibility and Business Ethics in Controversial Sectors: Analysis of Research Results. Journal of Entrepreneurship, Management and Innovation, 14, 111-126. https://doi.org/10.7341/20181435

Yamamoto, K., 2010. Educational and Public Accountability of Higher Education Institutions in Case of National Universities in Japan. The Journal of Management and Policy in Higher Education, 1-19. 


\section{ENTREPRENEURSHIP AND SUSTAINABILITY ISSUES}

ISSN 2345-0282 (online) http://jssidoi.org/jesi/

2020 Volume 8 Number 2 (December)

http://doi.org/10.9770/jesi.2020.8.2(66)

Make your research more visible, join the Twitter account of ENTREPRENEURSHIP AND SUSTAINABILITY ISSUES: @Entrepr69728810

Dr. Christiana KAPPO-ABIDEMI is a Senior lecturer at the School of Development Studies, Faculty of Economics, Development \& Business Sciences; University of Mpumalanga, South Africa. She holds a Doctorate, in Human Resource Management. She has worked and published in the areas of Human Resources and Public Administration, which are the areas of her expertise.

ORCID ID: orcid.org/0000-0001-9559-0514

Ogujiuba KANAYO holds a PhD in Development Economics and is a faculty member at the School of Development Studies, Faculty of Economics, Development \& Business Sciences; University of Mpumalanga, South Africa. His research has attracted citations from many other articles. He is currently working on several Entrepreneurship papers at the Centre for Entrepreneurship Rapid Incubator based at the University of Mpumalanga, South Africa. He has worked and published in the areas of Development Policy and Macroeconomics, which are part of his research focus areas.

ORCID ID: orcid.org/0000-0001-9155-7039

Copyright (C) 2020 by author(s) and VsI Entrepreneurship and Sustainability Center

This work is licensed under the Creative Commons Attribution International License (CC BY).

http://creativecommons.org/licenses/by/4.0/

c) (i) Open Access 